Section Editor

Mitchell S.V. Elkind, MD, MS

Jeong-Yoon Choi, MD Seol-Hee Baek, MD Jin-Man Jung, MD, $\mathrm{PhD}$ Do-Young Kwon, MD, $\mathrm{PhD}$

Moon Ho Park, MD, $\mathrm{PhD}$

Correspondence to Dr. Park: parkmuno@yahoo.co.kr

\section{Supplemental data} at Neurology.org

Download teaching slides: Neurology.org

\title{
Teaching NeuroImages: \\ Ocular bruit in carotid-cavernous sinus fistula
}

\section{Figure $1 \quad$ Physical examinations}
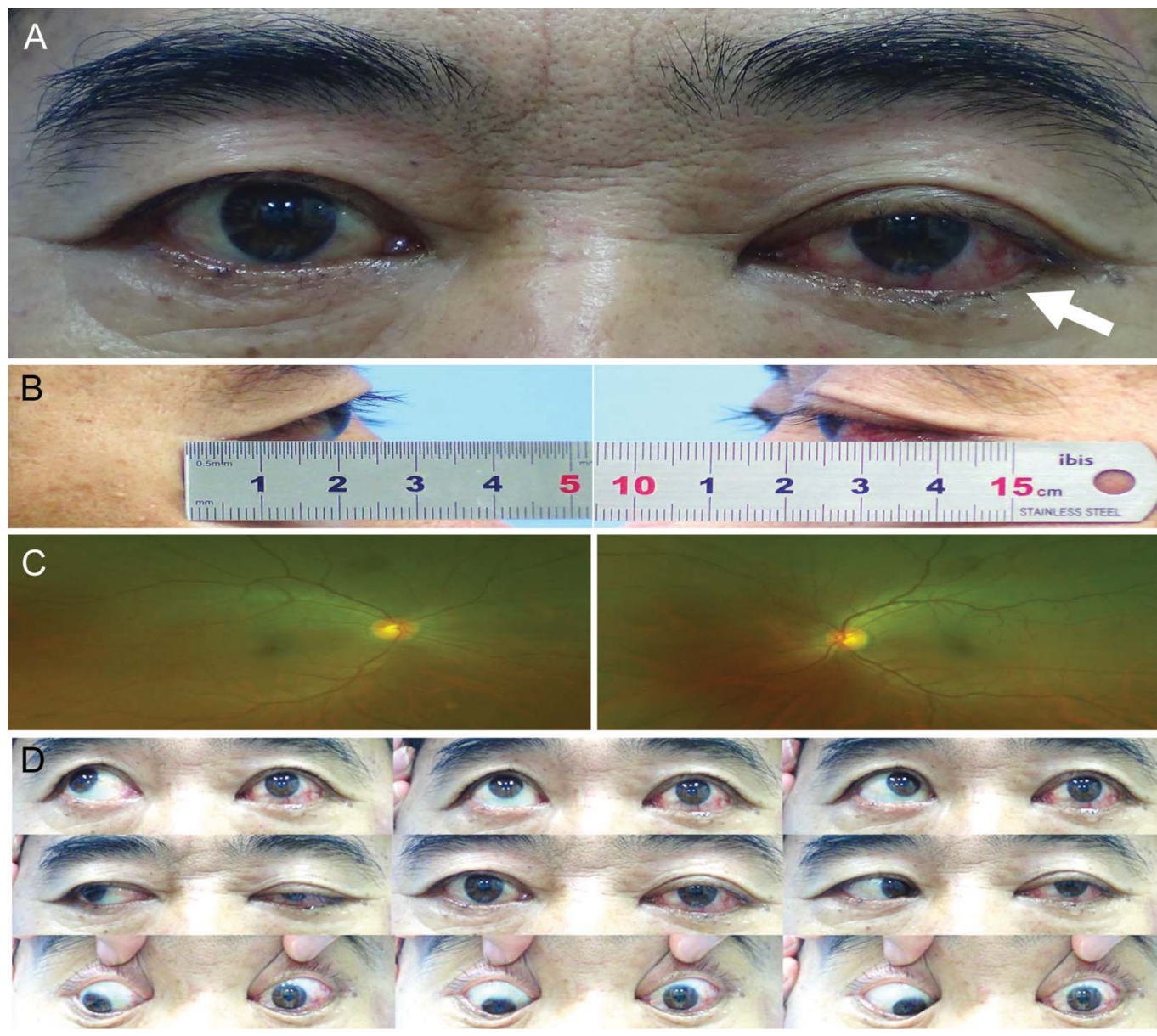

(A) Left eye with conjunctival injection and ptosis. (B) Left eye proptosis. (C) Fundus shows dilated veins with no hemorrhages or disc edema. (D) Ocular motility shows complete external ophthalmoplegia in left eye and partial limitation of abduction in right eye.

A 57-year-old man who had a traffic accident 1 month previously presented with left ocular pain, double vision, and left eye proptosis with ptosis and conjunctival hemorrhage. Fundus showed dilated veins with no hemorrhages or disc edema. Left ocular motility showed complete external ophthalmoplegia (figure 1). There was prominent ocular bruit in his left eye (audio file on the Neurology ${ }^{\circledR}$ Web site at Neurology.org). MRI and magnetic resonance angiography showed a dilated left superior ophthalmic vein and an extravasation into cavernous sinus (figure 2). With chemosis, ophthalmoplegia, and retro-orbital pain, the auscultation of orbital bruit can make a correct and prompt diagnosis in the patient with carotid-cavernous sinus fistula. ${ }^{1}$

\section{AUTHOR CONTRIBUTIONS}

Dr. Choi: participated in conceptualization of the manuscript, drafted the manuscript. Dr. Baek: participated in analysis of results and conceptualization of the manuscript. Dr. Jung: selected appropriate images and

From the Department of Neurology, Korea University College of Medicine, Ansan, Korea.

Go to Neurology.org for full disclosures. Funding information and disclosures deemed relevant by the authors, if any, are provided at the end of the article. 
Figure 2 Brain MRI and magnetic resonance angiography findings

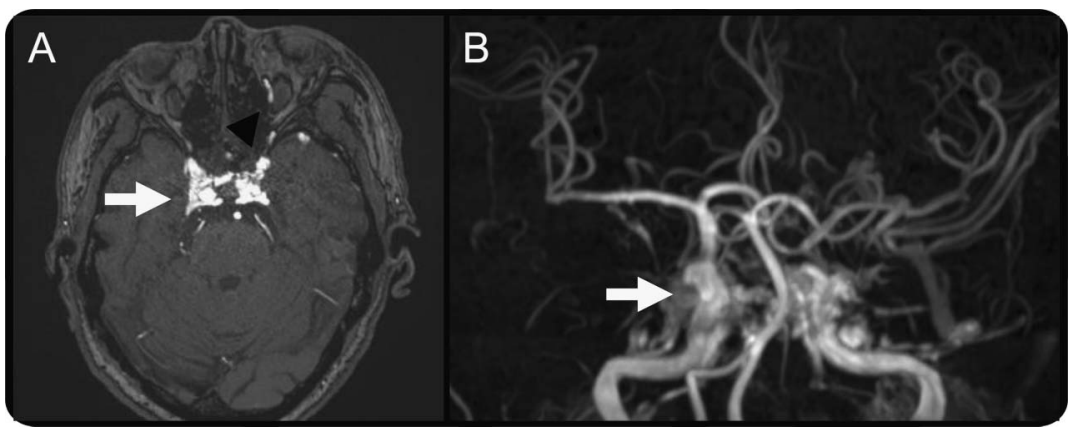

Contrast-enhanced MRI (A) and magnetic resonance angiography (B) show a dilated left superior ophthalmic vein (black arrowhead) and a extravasation into cavernous sinus (white arrow).

revised the manuscript for intellectual content. Dr. Kwon: participated in analysis of results and revised the manuscript for intellectual content. Dr. Park: drafted the manuscript and figure legend and revised the manuscript for intellectual content.

\section{STUDY FUNDING}

No targeted funding reported.

\section{DISCLOSURE}

The authors report no disclosures relevant to the manuscript. Go to Neurology.org for full disclosures.

\section{REFERENCE}

1. Ling JD, Chao D, Al Zubidi N, Lee AG. Big red flags in neuro-ophthalmology. Can J Ophthalmol 2013;48:3-7. 


\section{Neurology}

\section{Teaching NeuroImages: Ocular bruit in carotid-cavernous sinus fistula Jeong-Yoon Choi, Seol-Hee Baek, Jin-Man Jung, et al. Neurology 2014;83;e87-e88 \\ DOI 10.1212/WNL.0000000000000689}

\section{This information is current as of August 11, 2014}

\section{Updated Information \& Services}

\section{Supplementary Material}

\section{References}

Subspecialty Collections

Permissions \& Licensing

Reprints including high resolution figures, can be found at: http://n.neurology.org/content/83/7/e87.full

Supplementary material can be found at: http://n.neurology.org/content/suppl/2014/08/10/WNL.0000000000000 689.DC1

http://n.neurology.org/content/suppl/2014/08/10/WNL.0000000000000 689.DC2

This article cites 1 articles, 0 of which you can access for free at: http://n.neurology.org/content/83/7/e87.full\#ref-list-1

This article, along with others on similar topics, appears in the following collection(s):

\section{All Imaging}

http://n.neurology.org/cgi/collection/all_imaging

All Neuro-ophthalmology

http://n.neurology.org/cgi/collection/all_neuroophthalmology

Clinical neurology examination

http://n.neurology.org/cgi/collection/clinical_neurology_examination Other cerebrovascular disease/ Stroke

http://n.neurology.org/cgi/collection/other_cerebrovascular_disease_s troke

Information about reproducing this article in parts (figures,tables) or in its entirety can be found online at:

http://www.neurology.org/about/about_the_journal\#permissions

Information about ordering reprints can be found online:

http://n.neurology.org/subscribers/advertise

Neurology ${ }^{\circledR}$ is the official journal of the American Academy of Neurology. Published continuously since 1951, it is now a weekly with 48 issues per year. Copyright @ 2014 American Academy of Neurology. All rights reserved. Print ISSN: 0028-3878. Online ISSN: 1526-632X.

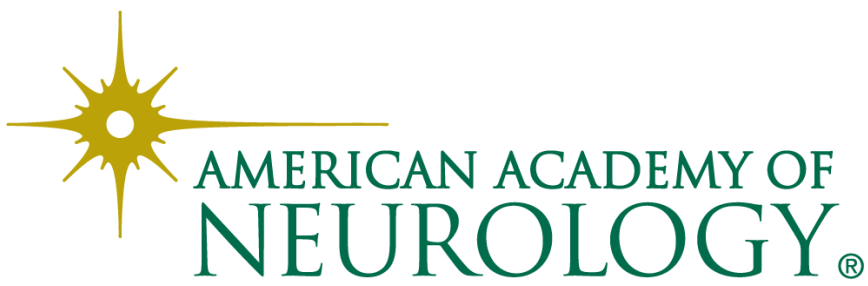

